$$
\text { 両側 Spigel ヘルニアの } 1 \text { 例 }
$$

\author{
豊田病院外科 \\ 原田直樹西尾吉 正豊田紘生
}

Spigel ヘルニアは腹横筋が筋成分から腱膜に移行する半月線上と腹直筋外縁との間 の Spigel 筋膜に発生する稀な腹壁ヘルニアの 1 つである. 今回われわれは, 左右両側に Spigel ヘルニアを認めた症例を経験したので報告する. 症例は60歳, 女性. 以前より虫 垂炎術後の腹壁疫痕へルニアを指摘されるも放置していたが, 右側の腫瘤の脱出が頻回 になり嘔吐, 疼痛を伴うようになり来院. 来院時右下腹部を中心として臍下部にかけて の小児頭大の腫瘤と左下腹部に $5 \mathrm{~cm}$ 大の膨隆を認めた. 手術創部近傍であり, 当初腹壁 属痕へルニアの診断で手術施行. 手術所見では, 弓状線より尾側で外腹斜筋腱膜下に左 右両側に手術痕部と異なる位置に, 腹膜前脂肪織を被ったヘルニア哓が確認された。両 側 Spigel ヘルニアと診断し, 手術はへルニア門を Marlex mesh を用いて閉鎖し終了し た. 術後経過順調で, 術後より 1 年の現在再発の徴候は認められていない.

索引用語：Spigel ヘルニア, 両側 Spigel ヘルニア

緒 言

Spigel ヘルニア (半月状線ヘルニア) は腹直筋外縁 の Spigel 筋膜に発生する稀な腹壁ヘルニアの 1 つで ある.われわれは, 左右両側の Spigel ヘルニアの 1 例 を経験したので本邦報告例の検討を加え報告する．

症例

症例：60歳, 女性.

主訴：下腹部腫瘤および疼痛.

家族歴：特記事項なし.

既往歴：33歳時虫垂炎にて虫垂切除,ドレナージ術. 妊娠中絶歴18回, 出産経験はなし。

現病歴：10年前より右下腹部腄瘤を自覚, 次第に増 大し近医受診するも腹壁痗痕へルニアと診断される。 以後そのまま経過観察とされ， 5 年前より自ら用手整 復を行っていた。 4 年前より, 時折右下腹部腫瘤と関 係なく左側にも新たに腫瘤を自覚するようになる．右 側の腫瘤の增大傾向認め, 半年前より腹痛, 嘔吐を伴 うようになり，2001年11月16日当院外来を受診.

入院時現症 : 身長 $140 \mathrm{~cm}$, 体重 $39 \mathrm{~kg}$, 栄養状態良好, 眼瞼結膜に貧血, 眼球結膜に黄疸を認めなかった. 胸

2003 年 3 月 3 日受付 2003 年 7 月 23 日採用

〈所属施設住所〉

㣙2-0023 大阪市淀川区十三東 $2-5-5$
部に異常所見は認められなかった．腹部は立位時に右 側腹部全体に小児頭大の膨隆を認め，用手的に容易に 返納されるも，直ちに再び膨隆を認めた. 左下腹部に も立位で腹圧をかけたときのみ, 胡桃大の膨隆が触知 された，右下腹部には交叉切開によると思われる虫垂 炎の手術創, および左側腹部にも虫垂炎手術時にドレ ーン留置されたとされる手術創部が認められた。返納 の際腱膜の脆弱さはうかがえたものの明らかな腱膜欠 損と思われる陥凹部は触知されなかった．その他腹部 には明らかな手術創,外傷痕は認められなかった(図 1). 入院時検查所見: 血液一般, 生化学検査, 尿検查に 異常はなかった。

腹部レントゲン：明かな所見は認めず.

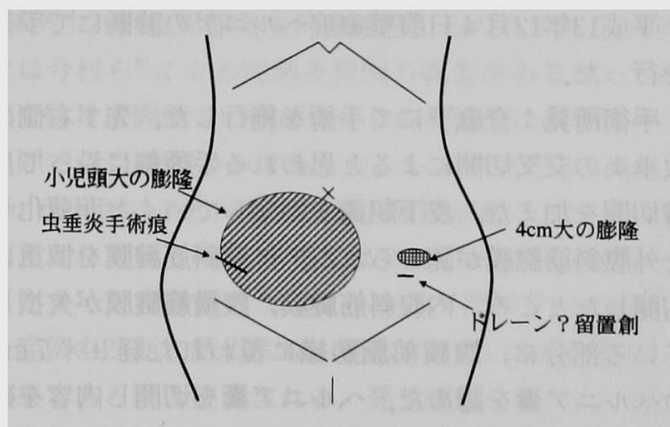

図 1 入院時所見 


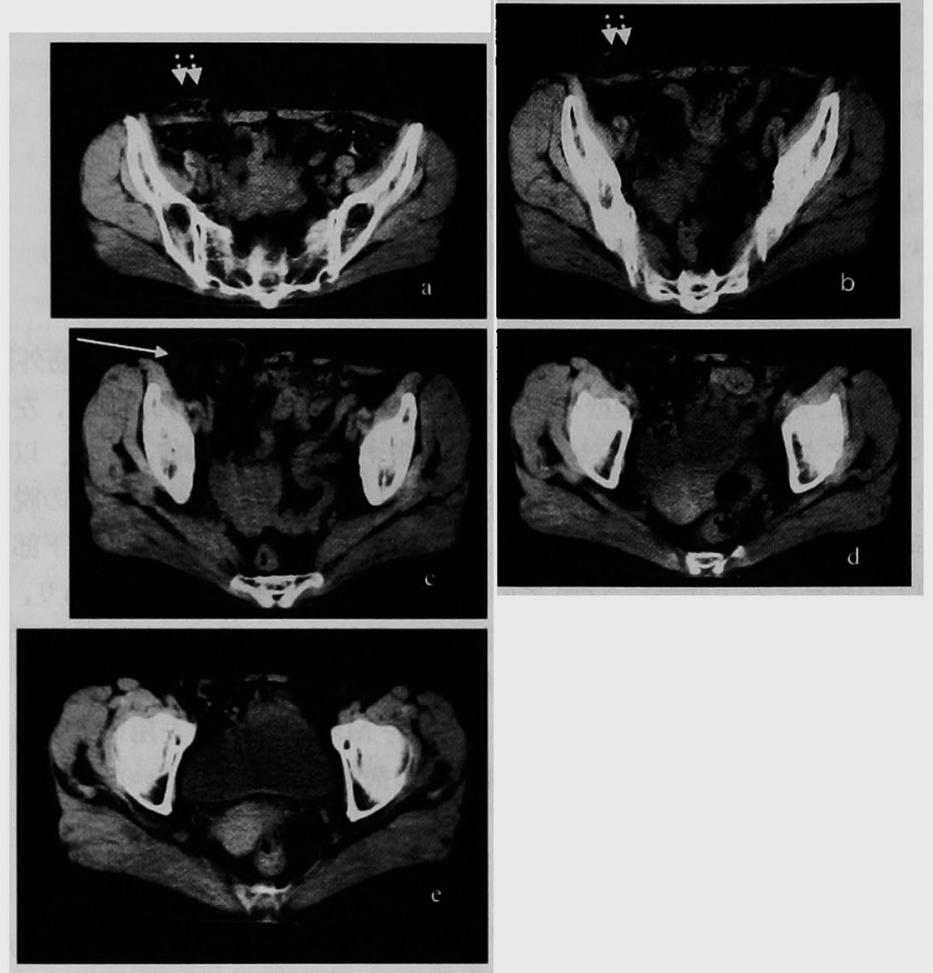

图 2 腹部 CT : 右腹直筋外側で大腿骨頭上縁の高さで, 腹腔内より脱出す る小腸と考えられる管腔構造 (実線矢印) を認め, 腹壁皮下に広がってい る(点線矢印)，左側ではあきらかな腹腔内容の脱出像は認めないものの， 外腹斜筋腱膜の菲薄化が確認された。

腹部超音波所見：厚い脂肪層を認め, 腱膜が全体に 菲薄化していた。明らかな腱膜欠損部は確認できなか った。

腹部 CT (図 2)：右下腹部の腹直筋外側で大腿骨頭 上縁の高さにて, 腹腔内より連続して腹壁皮下に脱出 する小腸と考えられる管腔構造が確認された，左側で はあきらかな腹腔内容の脱出像は認めないものの，外 腹斜筋腱膜の菲薄化が確認された。

平成 13 年 12 月 4 日腹壁洀痕ヘルニアの診断にて手術 を行った.

手術所見：全麻下にて手術を施行した，先ず右側の 虫垂炎の交叉切開によると思われる手術創に治って皮 涌切開を加えた．皮下組織を剝離していくと菲薄化し た外腹斜筋腱膜が認められた。外腹斜筋腱膜を慎重に 切開したところ, 内腹斜筋腱膜, 腹横筋腱膜が欠損し ている部分に, 腹膜前脂肪織に覆われた経 $9 \times 7 \mathrm{~cm}$ のヘルニア慗を認めた。へルニア箕を切開し内容を確 認したところ，直視下に小腸が認められたがへルニア
襄と腹腔内臟器の疮着は存在しなかった。へルニア門 は下腹壁動静脈の尾側に存在した(図 3 )。 なお，外腹 斜筋腱膜を皮下組織より豩離し検索した所，虫垂切除 部の手術痕は同部と異なるところに存在しており直接 的な因果関係がないことを確認した。へルニア裹に肋 下神経あるいは腸骨下腹神経前皮枝と思われる神経が 癒着していた。ヘルニア䧶を吸収系で縫合閉鎖した後, 外腹斜筋腱膜も菲薄化し Hasselbalch三角の脆弱さ も認められたため, Marlex mesh を腹直筋筋膜 (前後 鞘）と腹横筋腱膜と内腹斜筋腱膜に縫合固定した．外 腹斜筋腱膜は結節縫合にて閉鎖した．左側も同様にア プローチしたところ外腹斜筋腱膜の菲薄化は右側に比 べ軽度で, ヘルニア亸も経 $4 \times 3 \mathrm{~cm}$ と小さかったが 同じく Hasselbaich 三角の脆弱が認められたため, Marlex mesh を同様に縫合固定し手術を終了した.

術後経過：術後両側にあった所見は消失し, 経過は 順調で術後 1 年の現在, 再発の徴候は認められていな い(図4). 


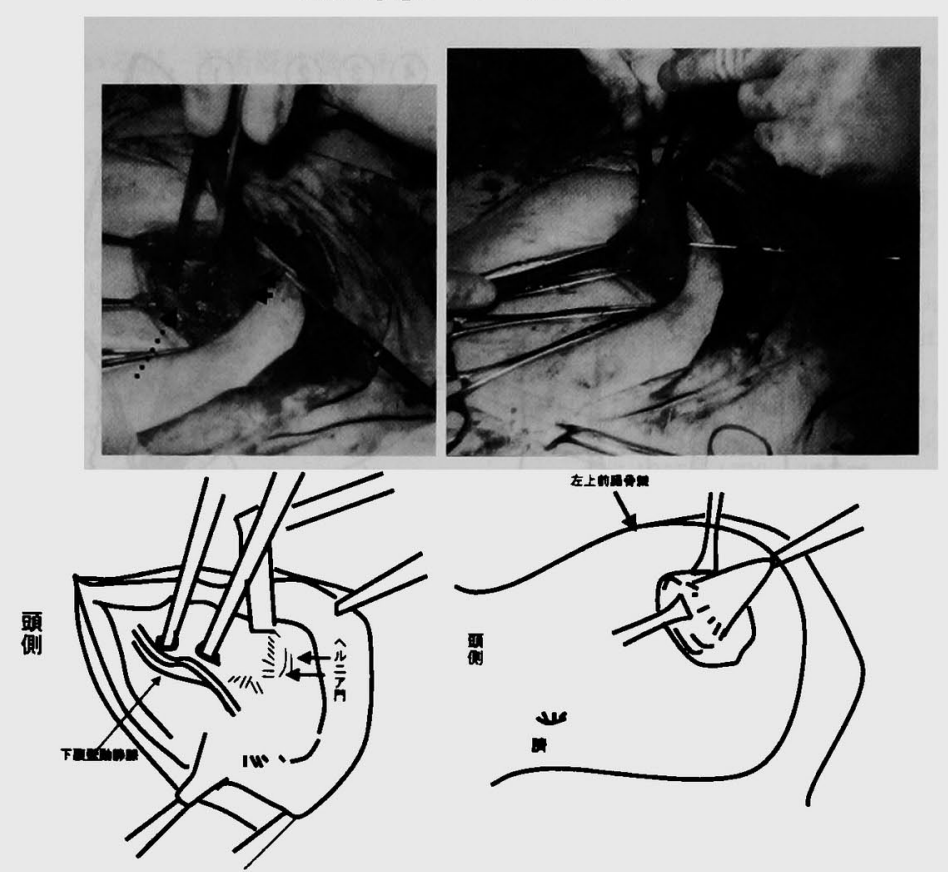

図 3 術中写真 $(\mathbf{a}, \mathbf{b})$ とシェーマ (c, d) : a ) 右外腹斜胼腱膜を切開 low Spigelian hernia の hernia 門 (実線矢印), 下腹壁動静脈 (点線矢印). 尾側にヘルニア門を認め, low Spigelian hernia と確認された. b) 同じ レペルでの左 hernia sac. c) a のシェーマ. d) bのシェーマ. $\frac{a}{b}$

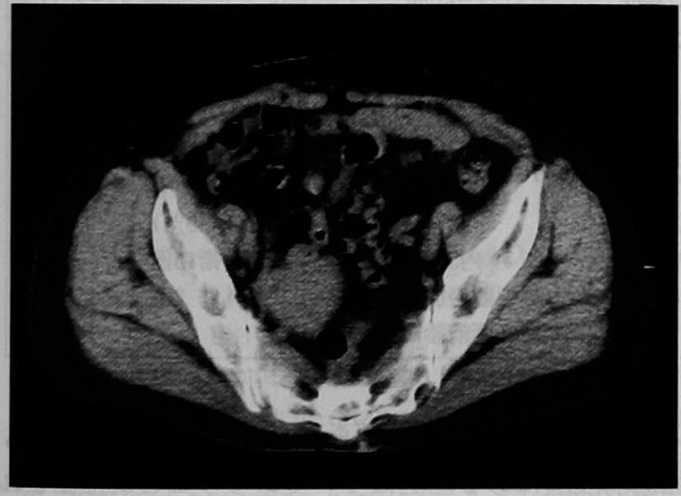

図 4 腹部 CT 所見（術後 1 年目）：ヘルニア門は修復さ れており, 再発を認めない.

\section{考察}

Spigel ヘルニアは腹横筋が筋成分から腱膜に移行 する半月線上と腹直筋外縁との間の Spigel 筋膜に発 生するヘルニアリで，稀な腹壁ヘルニアの1つである

(図 5 a， b ). 1764年に Klinklosch 2)の報告以来, 文 献上散見されるようになった。発生頻度は全腹壁へル
ニアの $2 \%$ 以下党とされており，本邦では本症例を加 え検索しえた範囲では56例報告されているが，疾患の 概念が乏しく一般の腹壁ヘルニアとして扱われるもの や，臨床所見がはっきりしないため報告されない例も 多く,実際にはもう少し頻度の高い疾患と考えられる。 年秢は生後 6 力月から83歳 (平均53.5歳) ${ }^{4)}$, 男女比 $0.64 ： 1$ とやや女性に多く,左右比は $1.1 ： 1$ と左右差 は認めず諸家の報告 ${ }^{15)}$ とも一致していた(表 1 ). 年齢 層は比較的広範囲にわたるが高齢者に多い傾向がうか がえた. 多発例の報告は少なく，欧米では Spangen ${ }^{11 か ゙ ~}$ 876例中 29 例の両側発生例を報告するのみであり, 本邦 では今村ら ${ }^{6)} に よ る$ 同側多発例の報告があるが，外傷 例を除けば両側での同部位からの発症例は確認しえた 範囲では自験例のみであった。ヘルニア門は0.5〜2 $\mathrm{cm}$ と小さいことが多く嵌頓, 校扼が起こりやすい原 因とされている゙が，本邦では $2 \mathrm{~cm}$ 以上の報告例が72 \%と多く，自験例のようにへルニア門が $5 \mathrm{~cm}$ を超え る症例も $28 \%$ に認められ，見逃されている症例が多い 結果であろうと推測される. 発生誘因としては, 極度 の肥満やるいそう, 頻回の出産, 重労働, 腹水, 外科 


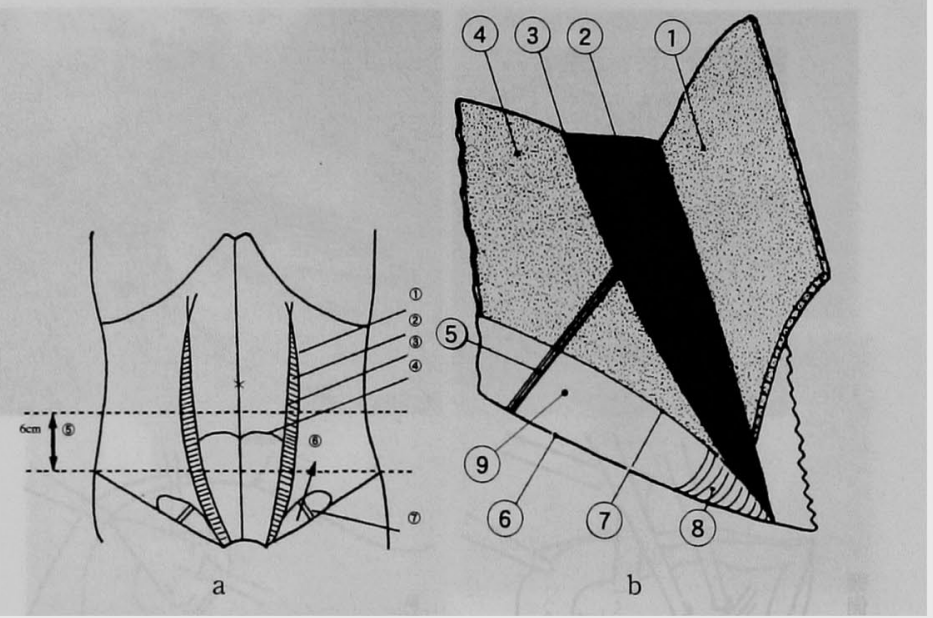

図 5 Spangen Lによる模式図

a Spigel ヘルニア発生模式図 (1)半月線(2) Spigel 腱膜(3)腹直筋 外縁(4)弓状線(5) Spigelian hernia belt (6) low Spigel hernia (7) 深下 腹壁動静脈 (Spangen L, 1989引用))

b Hesselbach's 三角の模式図 (1)内腹斜筋(2) Spigelian 腱膜(3)半 月線(4)腹横筋(5)下腹壁動静脈(6)鼠径靶帯(7)腹横筋腱膜弓(8)最径鎌

(9) low Spigelian hernia)

表 1 Spigel ヘルニア本邦報告56例

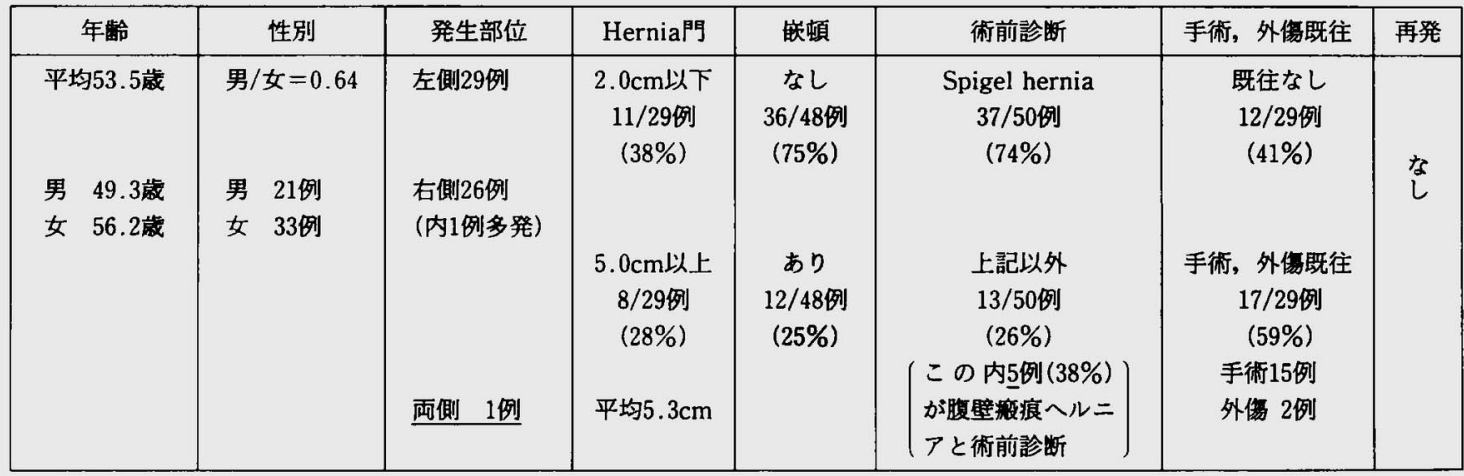

手術既往や外傷などが関与するとされている，特に下 腹部を中心とした手術, 外傷の既往例は29例中17例(59 \%) と比較的高率に存在する.しかし，このヘルニア が先天性なのか後天性なのかは明らかにはされていな い.Zimmerman ら”は500例の剖検例を検討し,腹横筋 腱膜の欠損 $16.4 \%$ の症例に, 内腹斜筋腱膜の欠損部が $21.8 \%$ 症例に存在すると報告しているが, 自験例で は左右両側に所見があり，右側はへルニア門が $10 \times 8$ $\mathrm{cm}$ と大きく手術の既往や病悩期間も 10 年と長期間に わたることから, ある程度の筋膜欠損に後天的要素が 加わって臨床的にヘルニアとして出現した可能性が高
いと考えられた. 実際, 明らかな臨床症状がなくても， 発症前段階にある症例は多いであろうことが推測され る.また，外腹斜筋腱膜の下に発生するものは特に masked hernia ${ }^{1889)}$ と言われており，小さいへルニアて あった場合診断は困難であるとされているが，自験例 も腱膜の脆弱化も強くへルニア門の明かな範囲は触診 上不明であった，嵌頓する頻度は本邦の集計で25\%て あり, Spangen"の集計した $21.2 \%$ とほほ致してお り比較的高い頻度で出現すると考えられる．嵌頓しイ レウス症状をきたしたもの以外の症例の検討では, 理 学的所見や，また近年では腹部 $\mathrm{CT}{ }^{10)}$ などから術前に 
診断される報告が増加しているが，手術既往歴のある ものが多いため, 腹壁瘕痕ヘルニアプの術前診断であ ったものも10\% ( 5 例 : Spigel hernia 以外の診断であ った症例の38\%）に認め，その鑑別が必要であると考 えられた。 また，自験例では施行しなかったがCTに よる検查時は腹卧位で行う方が、ヘルニア門の範囲や masked hernia の場合, 確定診断に有用であろうと思 われた.一方近年では疾患の概念も普及されつつあり, また画像診断の進歩によって発見される報告例 ${ }^{1112123}$ 年々増加しており，今後稀な垁患ではなくなっていく ことが予測される.治療としては唯一手術が根治的治 療となる，通常嵌頓，絞拒がないかぎりへルニアサッ クの処理は不要であり，ヘルニア門が小さいときは直 妾ヘルニア門を縫合閉鎖し，自験例のようにへルニア 門が大きく腱膜の脆弱化が強い場合, Marlex mesh の ような補強 ${ }^{13114) を}$ を行い確実な閉鎖を行うことが再発防 止の意味を含めて重要であると考えられた。

$$
\text { 結語 }
$$

原発性腹壁ヘルニアの中でも稀とされる Spigel へ ルニアを両側に認めた症例を経験したので，若干の文 献的考察を加え報告した。

本論文の要旨は，第64回日本臨床外科学会総会に於いて 発表した.

\section{文 献}

1) Spangen $L$ : Spigelian hernia. World J Surg 13 : $573-580,1989$

2) Klinklosch JT:Spontaneous lateral ventral hernia. Ann Surg $75 ; 677-685,1922$

3) Holder LE, Schneider HJ : Spigelian hernia. Anatomy and rentgenographic manifestiations. Radiology 112 : 309-313, 1974

4）窪田公一, 高橋 弘, 小川健治他：明瞭な CT 像 を呈した Spigel ヘルニアの1 例。日臨外会誌 63: 491-494, 2002

5) Nangendran $T$, Ujjin $V$, Drakes $D:$ Spigelian Hernia : Case report. Millitary Medicine 148: $164-169,1983$

6) 今村 秀, 安蘓正和, 三井信介他：イレウスを毠 症した Spigel ヘルニア多発の 1 例。日臨外会誌 $62: 1315-1320,2001$

7) Zimmerman LM, Anson BJ, Morgan EH, et al : Ventral hernia due to normal banding of the abdominal muscles. Surg 78:536-540, 1944

8) Uchiyama $K$, Shibuya $T$, Watanabe $Y$, et al: Spigelian hernia. 日医大誌 $65: 55-57,1998$

9）浦橋泰然，吉井克己：絞拒性イレウスを示した Spigel ヘルニア嵌頓の 1 例. 日臨外会誌 60 ： $1398-1401,1999$

10）沢井博純,倉橋伸吾，山中雄二他：術前腹部 CT 検 查にて診断しえた Spigel ヘルニアの 1 例. 日臨外 医会誌 $58: 2700-2703 ， 1997$

11）大輪芳裕, 鉿村和義, 小島 卓他：S 状結腸が嵌頓 した Spigel ヘルニアの 1 例. 日臨外会誌 61： $509-512,2000$

12）翼 博臣, 染谷折史, 戸塚守夫他: Spigel ヘルニ アの 1 例. 日臨外会誌 $61: 513-517,2000$

13）貞永摩美華, 石川雅健, 蘇我幸弘：Spigel ヘルニ アの1例. 日救急医会関東誌 $20: 266-267,1999$

14）山本協二，梅澤昭子，德村弘実他：右季肋部に発 生した大きな Spigel ヘルニアの 1 例. 日臨外会誌 $59: 1423-1427,1998$

\title{
A CASE OF BILATERAL SPIGELIAN HERNIA
}

\author{
Naoki HARADA, Yoshimasa NISHIO and Hiroo TOYODA \\ Department of Surgery, Toyoda Hospital
}

Spigelian hernia occurs on the Spigelian aponeurosis between the semilunar line from which the fiber of transversus muscle changes to aponeurosis and the lateral margin of the rectus abdominis muscle. Spigelian hernia is considered an uncommon spontaneous hernia of the abdominal wall. We report a case of bilateral Spigelian hernias. A 60-year-old woman who has been diagnosed as having abdominal incisional hernia after an operation for appendicitis, but she had let it alone was seen at the hospital because of recurrent swelling and accompanying abdominal pain and vomiting for recent 6 months. On physical examination, an infant-head-sized tender mass was present in the right lower quadrant and a $5 \mathrm{~cm}$ in diameter, in the left lower quadrant of the abdomen. These masses were located near the scar of the operation. We initiate surgery with a diagnosis of abdominal incisional hernia. At surgery, hernia sacs with covering preperitonial fat were found under the thin external abdominis oblique aponeurosis, below the linea arcuata, and these positions were different from postoperative scars. The bilateral hernias were diagnosed as Spigelian hernia, and each orifices was closed by Marlex mesh repair. The patient has been in good health without any signs of recurrence, as of 12 months after the operation. 